\title{
$\mathrm{NH}_{4} \mathrm{HS}$ 環境における新防食設計手法の確立
}

\author{
鳥羽和宏*, 川野浩二*, 酒井潤一** \\ * 出光エンジニアリング株式会社 技術部 \\ ** 早稲田大学 理工学術院
}

\section{Development of a New Design for Corrosion Prevention in $\mathrm{NH}_{4} \mathrm{HS}$ Environments}

\author{
Kazuhiro Toba*, Koji Kawano* and Jun' ichi Sakai** \\ * Idemitsu Engineering Co., Ltd \\ ** Faculty of Science and Engineering, Waseda University
}

\begin{abstract}
$\mathrm{NH}_{4} \mathrm{HS}$ corrosion has been a serious problem in oil refining plants. The corrosion rate dramatically increases over a certain concentration of $\mathrm{NH}_{4} \mathrm{HS}$. In high pressure plants such as hydrodesulfurization units which are operating in $\mathrm{NH}_{4} \mathrm{HS}$ environments, leakage caused by corrosion could result in catastrophic disaster. Therefore, in the design phase, corrosion prevention techniques should be considered. In this study, a new design philosophy to prevent $\mathrm{NH}_{4} \mathrm{HS}$ corrosion in a sour water environment was successfully developed based on simulation techniques.
\end{abstract}

Key words : $\mathrm{NH}_{4} \mathrm{HS}$, ammonium salts, design, sour water

1. 緒

言

\section{1 背 景}

石油精製装置では，原油からガソリン，ジェット燃料， 灯油・軽油・重油等の石油製品を製造する過程で, 原油 中に含まれる硫黄化合物, 窒素化合物といった不純物を 除去する必要がある，そのため，水素化脱硫装置により 硫黄化合物を $\mathrm{H}_{2} \mathrm{~S}$ に転換 - 除去し, 製品中の硫黄分を低 減させる. 同時に窒素化合物から $\mathrm{NH}_{3}$ が生成するため, 脱硫装置の反応塔下流では, $\mathrm{H}_{2} \mathrm{~S}, \mathrm{NH}_{3}$ を含む流体が生成 する。このような環境では, $\mathrm{NH}_{4} \mathrm{HS}$ が生成し腐食環境が 形成される. $\mathrm{NH}_{4} \mathrm{HS}$ が高濃度で存在すると, 炭素鋼だけ でなくSUS316 ステンレス鋼においても急激に腐食が進 行する.このために, 水素化脱硫装置では, 水注入によ り $\mathrm{NH}_{4} \mathrm{HS}$ を希釈する対応をとっているが, 熱交換器千 ューブ内では, 不均一分散により局所的に高濃度となる 場合がある。このように, 潜在的に腐食の過酷度の高い 機器には, チューブ材質にAlloy 825 などの高合金を採 用する場合がある。更に, 脱硫装置下流の廃水処理装置 では, プロセス廃水から $\mathrm{H}_{2} \mathrm{~S}, \mathrm{NH}_{3}$ を除去するため, 廃 水ストリッパー塔頂系では高濃度の $\mathrm{H}_{2} \mathrm{~S}, \mathrm{NH}_{3}$ を含む腐 食環境となる。

また，石油産業活性化センターの報告書によると，国 内石油精製会社へのアンケート調査結果1) では, $\mathrm{NH}_{4} \mathrm{HS}$ 腐食環境での腐食モニタリングのニーズが最も高いこと が分かっている。更に，近年欧米石油会社を中心に， $\mathrm{NH}_{4} \mathrm{HS}$ による腐食に関する JIP (Joint Industrial Program）が形成され，コンソーシアムによる研究が行 われている2）ことからも, 当腐食における業界での課題

* =261-8501 千葉市美浜区中瀬 1-3 (1-3, Nakase, Mihama-ku, Chiba, 261-8501 Japan)

** 7 169-8555 東京都新宿区大久保 3-4-1 (3-4-1, Okubo, Shinjukuku, Tokyo, 169-8555 Japan)
は大きいことがうかがえる。

\section{$1.2 \mathrm{NH}_{4} \mathrm{HS}$ による腐食について}

$\mathrm{NH}_{4} \mathrm{HS}$ による腐食は，石油精製装置において水素化脱 硫・分解装置, 廃水処理装置で発生する腐食の一種で, $\mathrm{H}_{2} \mathrm{~S}, \mathrm{NH}_{3}, \mathrm{H}_{2} \mathrm{O}$ を含む環境で発生する. Damin ら ${ }^{3)}$ は, $\mathrm{NH}_{4} \mathrm{HS}$ の濃度が $35 \mathrm{wt} \%$ を境にして, 以下のように反応 が変化すると推定している。

$$
\begin{aligned}
& \mathrm{Fe}+\mathrm{H}_{2} \mathrm{~S} \rightarrow \mathrm{FeS}+\mathrm{H}_{2}\left(\mathrm{NH}_{4} \mathrm{HS} 35 \mathrm{wt} \% \text { 未満 }\right) \\
& \mathrm{FeS}+6 \mathrm{NH}_{4} \mathrm{HS} \rightleftarrows\left[\mathrm{Fe}\left(\mathrm{NH}_{3}\right)_{6}\right]^{2+}+6 \mathrm{H}_{2} \mathrm{~S}+\mathrm{S}^{2-}
\end{aligned}
$$

$\left(\mathrm{NH}_{4} \mathrm{HS} 35 \mathrm{wt} \%\right.$ 以上)

[ ］：錯イオンを示す

この腐食は，濃度と流速の影響を大きく受ける，通常， $\mathrm{H}_{2} \mathrm{~S}$ 環境下では, Fig. 1 に示されるように, 流体中の $\mathrm{H}_{2} \mathrm{~S}$ により材料表面は硫化鉄皮膜が形成され，これが防食皮 膜の役割を果たす。但し, $\mathrm{NH}_{4} \mathrm{HS}$ 環境で流速が高くなる と, Fig. 2 のように硫化鉄皮膜は剥離，修復を繰り返し， 減肉は進行していく.また, 流速が低くても, $35 \mathrm{wt} \%$ 以 上の高濃度となると，(2)の反応式に示されるように， 錯イオンを生成し，硫化鉄皮膜や金属表面を溶解させ， 年間数 $\mathrm{mm}$ から数十 $\mathrm{mm}$ の減肉を引き起こす激しい腐食 となる (Fig. 3) と推定されている. Damin ら³) が実施し た実験結果によると， $\mathrm{NH}_{4} \mathrm{HS}$ 濃度が $35 \mathrm{wt} \%$ 以上となる と, 炭素鋼だけでなく, SUS316 ステンレス鋼でも腐食 速度が急激に増加することが示されている．但し，(2) の式にて示されている錯イオンの存在について確認はさ れておらず，この腐食機構については，推定の域を超え ていない。また，石油業界では，20 年以上にわたり Damin らの実験結果を高濃度の $\mathrm{NH}_{4} \mathrm{HS}$ 腐食環境での評 価に使用しているにも関わらず，その具体的な実験手法 などが示されていない.

また，実装置では， $\mathrm{NH}_{4} \mathrm{HS}$ 環境が局所的にどの部位で 濃縮するかを評価するための確立された手法がない．前 述の Damin らのデータによるような挙動を示す場合, あ る濃度を超えると腐食速度は急激に加速されるため, 局 


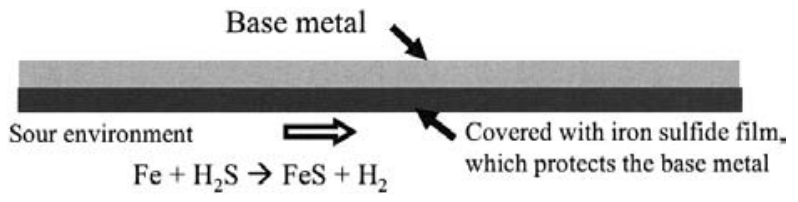

Fig. 1 Schematic diagram of corrosion prevention of steels in sour environments.

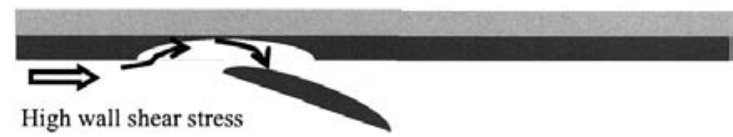

Fig. 2 Schematic diagram of corrosion on steels in $\mathrm{NH}_{4} \mathrm{HS}$ solution with high shear stress.

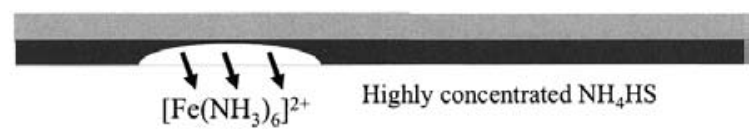

Fig. 3 Schematic diagram of corrosion on steels in highly concentrated $\mathrm{NH}_{4} \mathrm{HS}$ solution.

部での濃度推定手法の確立が求められる.

\section{3 高濃度 $\mathrm{NH}_{4} \mathrm{HS}$ による腐食機構の解明検討}

$\mathrm{NH}_{4} \mathrm{HS}$ 環境での腐食を議論する際に， $\mathrm{NH}_{4} \mathrm{HS}$ が 35 $\mathrm{wt} \%$ 以上となる環境において，腐食速度が急激に加速す る現象が本当に起こり得るのか，また， $\mathrm{NH}_{4} \mathrm{HS}$ が 35 $\mathrm{wt} \%$ 以上となる高濃度の環境では，どのような機構で腐 食が進行するのかを明確にする必要がある.

そこで，著者らは，オートクレーブによる高濃度 $\mathrm{NH}_{4} \mathrm{HS}$ 水溶液での浸漬試験を実施し, 得られた腐食速度 をDamin らのものと比較するとともに, 試験後の溶液分 析による腐食生成物の同定の結果から, 腐食機構を解明 した。

\section{4 局所的に高濃度の $\mathrm{NH}_{4} \mathrm{HS}$ が生成する機構解明}

高濃度の $\mathrm{NH}_{4} \mathrm{HS}$ 環境で激しく腐食が進行することが 確認された場合においても, 実装置の機器・配管のどの 部位において高濃度の $\mathrm{NH}_{4} \mathrm{HS}$ が形成されるのかが解明 できなければ，設備の信頼性向上にはつながらない。そ こで，水素化脱硫装置の下流設備である廃水ストリッパ 一での $\mathrm{NH}_{4} \mathrm{HS}$ による腐食解析事例4) を基に, 高濃度の $\mathrm{NH}_{4} \mathrm{HS}$ が生成する機構を解明したので, その内容につい て述べる。

\section{2. 実 験}

\section{1 腐 食 試 験}

試験片には炭素鋼（JIS G 3101 SS400），ステンレス鋼 （JIS G 4305 SUS316L）を用いた。試験溶液は，窒素䨌囲 気で濃度調整したアンモニア水に硫化水素ガスを飽和さ せて, 室温で $\mathrm{NH}_{4} \mathrm{HS}$ 濃度を調整した。 また, 溶存酸素 による影響を低減するために，試験溶液にはヒドラジン を添加した。これら試験溶液を, 大気と接触させずに, 窒素封入したオートクレーブに挿入し， $90^{\circ} \mathrm{C}$ まで昇温し
た. 試験濃度は 30, 39, $43 \mathrm{wt} \%$ の 3 条件とした。本試験 溶液中に SS400 および SUS316L ステンレス鋼の試験片 を 24 時間浸漬し, 静置させ, 重量減法を用いて腐食速 度を測定した。

\section{2 腐食生成物の分析}

試験終了後，炭素鋼の腐食生成物を確認するため，試 験片表面の EDX (Energy Dispersive X-ray Spectroscopy) 定性分析およびX 線回折を行った。また，試験溶液の XANES (X-ray Absorption Near Edge Structure) スペク トルを測定し，シミュレーションを用いた鉄系化合物の 理論解析結果とのカーブフィッティング法により，試験 溶液中の鉄系腐食生成物の存在形態を推定した。

\section{3. 結果}

\section{1 実験室試験による腐食速度に及ぼす $\mathrm{NH}_{4} \mathrm{HS}$ 濃度 の影響}

Fig. 4 に炭素鋼および SUS316L ステンレス鋼の腐食速 度の測定結果を示す ${ }^{5)}$. $30 \mathrm{wt} \%$ 以上の $\mathrm{NH}_{4} \mathrm{HS}$ 濃度では, 流速がない環境でも炭素鋼は $10 \mathrm{~mm} / \mathrm{y}$ 以上の腐食速度 であった5), 6).ステンレス鋼も $40 \mathrm{wt} \%$ 付近の $\mathrm{NH}_{4} \mathrm{HS}$ 濃 度では約 $3 \mathrm{~mm} / \mathrm{y}$ の腐食速度で激しく腐食した。岩脇 ら 7)による $1 \mathrm{wt} \%$ および $7 \mathrm{wt} \% \mathrm{NH}_{4} \mathrm{HS}$ 濃度で測定した腐 食速度と比較すると, 高濃度 $\mathrm{NH}_{4} \mathrm{HS}$ 環境は炭素鋼に対 して激しい腐食性を有することが分かる。これらにより， 高濃度 $\mathrm{NH}_{4} \mathrm{HS}$ 環境では, Damin らの研究と同等の結果 が得られた。

試験終了後の炭素鋼試験片には激しい減肉が確認さ れ，表面には剥離しやすい腐食生成物が堆積していた。 EDX 定性分析の結果，これら堆積物では $\mathrm{S}, \mathrm{Fe}, \mathrm{O}$ が検出 され, $\mathrm{X}$ 線回折の結果, 主に硫化鉄 $\left(\mathrm{Fe}_{x} \mathrm{~S}_{y}\right)$ が同定され た。また，試験終了後の試験溶液は，いずれの濃度にお いても黒色沈殿物を有していた。 $43 \mathrm{wt} \% \mathrm{NH}_{4} \mathrm{HS}$ 濃度の 試験溶液の XANES スペクトル解析の結果, 黒色沈殿物 を含む試験溶液中では，Fe は主にへキサアンミン鉄イオ ン $\left(\left[\mathrm{Fe}\left(\mathrm{NH}_{3}\right)_{6}\right]^{2+}\right)$ およびマグネタイト $\left(\mathrm{Fe}_{3} \mathrm{O}_{4}\right)$ の状態 で存在している可能性が示された。また，テトラアンミ ン鉄イオン $\left(\left[\mathrm{Fe}\left(\mathrm{NH}_{3}\right)_{4}\right]^{+}\right)$, ペンタアンミン鉄イオン

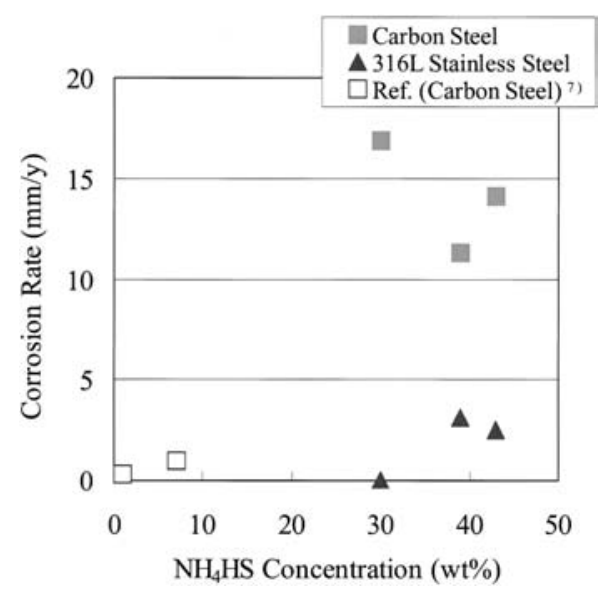

Fig. 4 Effect of $\mathrm{NH}_{4} \mathrm{HS}$ concentration on corrosion for carbon steel and Type 316L SS. 
$\left(\left[\mathrm{Fe}\left(\mathrm{NH}_{3}\right)_{5}\right]^{2+}\right)$, 二硫化鉄 $\left(\mathrm{FeS}_{2}\right)$ の存在も示唆された. 以上の結果より，高濃度 $\mathrm{NH}_{4} \mathrm{HS}$ 環境では，腐食 生成物として, 酸化鉄 $\left(\mathrm{Fe}_{3} \mathrm{O}_{4}\right)$ や二硫化鉄 $\left(\mathrm{FeS}_{2}\right)$ と いった固体成分のみならず，鉄のアンミン錯イオン $\left(\left[\mathrm{Fe}\left(\mathrm{NH}_{3}\right)_{X}\right]^{2+}\right)$ の存在が認められたことから, 激しい 腐食にはアンミン鉄イオンの生成が関与している可能性 がある。

\section{2 実装置での腐食状況}

本研究にて解析を実施した装置は, 水素化脱硫装置の 下流設備である廃水処理装置である. 当該装置は, 水素 化脱硫装置にて生成した $\mathrm{H}_{2} \mathrm{~S}, \mathrm{NH}_{3}$ を含む廃水から, $\mathrm{H}_{2} \mathrm{~S}$, $\mathrm{NH}_{3}$ を除去し，水を再使用するために設置される．Fig. 5 に廃水処理装置の概略フローを示す. $\mathrm{H}_{2} \mathrm{~S}, \mathrm{NH}_{3}$ を含む 廃水は, 廃水ストリッパーに入り, 再沸器にて塔内で加 熱された後, $\mathrm{H}_{2} \mathrm{~S}, \mathrm{NH}_{3}$ 含有ガスは塔頂へ移行する. 塔頂 から出た高濃度の $\mathrm{H}_{2} \mathrm{~S}, \mathrm{NH}_{3}$ を含む水蒸気は, 空冷式熱 交換器にて冷却され, 凝縮水の一部は系外に排出され, 残りは再度廃水ストリッパーに戻される. また, 塔頂ガ スは硫黄回収装置にて処理される.

腐食が発生したのは, 廃水ストリッパー塔頂空冷式熱 交換器チューブである. 空冷式熱交換器のヘッダータイ プは 1 パス，4段，チューブ材質は SUS316L ステンレス 鋼である (Fig. 6). 当該熱交換器は, 最下段チューブ (No. 4 チューブ）の下側に設置されているファンにより， 熱交換器の下側から空気が送り込まれ，上側から排出さ れる構造となっている.

腐食は空冷式熱交換器チューブにて発生した。激しい 腐食は最下段チューブの出口部に集中していた。流体は 熱交換器チューブ内では冷却されながら流れていくた め，チューブ出口部の方が入口側よりも流体温度は低く なる.また, Fig. 6 に示すように, 空冷式熱交換器の下 側から冷媒である空気が入るため, 最下段チューブにお いて最も流体温度が低くなっている.すなわち, 腐食は 温度の低い箇所で顕著となった。但し, 最下段チューブ

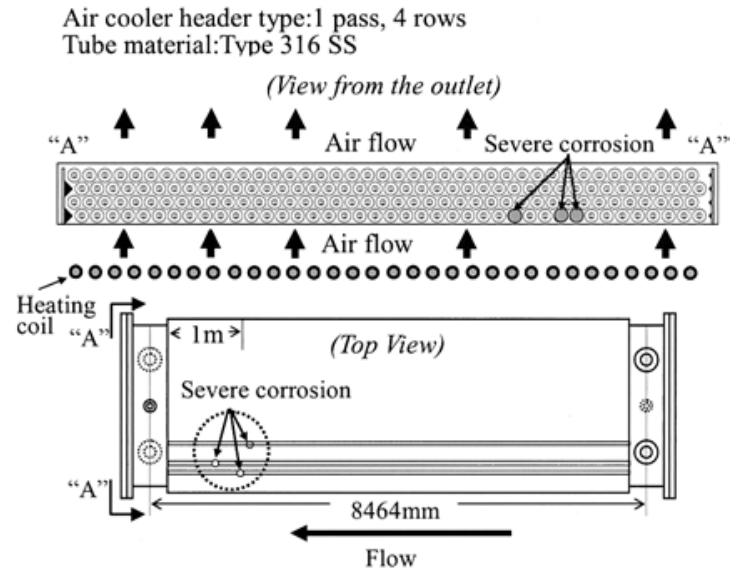

Fig. 6 Location of the corrosion in the air cooler.

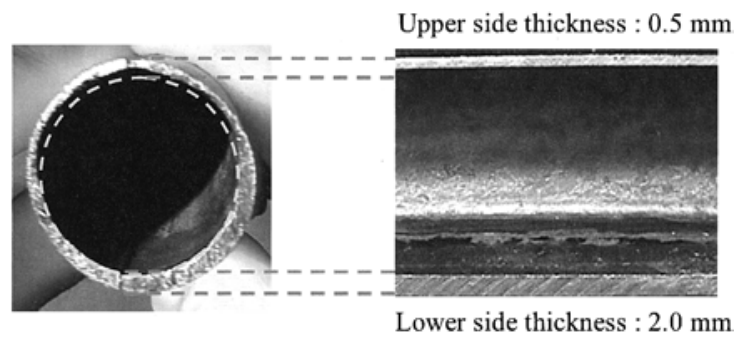

Fig. 7 Visual observations of the corroded tube.

においても健全なチューブが存在していた.

また Fig. 7 のように，腐食したチューブでは，チュー ブの気相部となる上部で減肉が激しく金属光沢を認めた が，液相となる下部には黒色スケールに覆われており， 減肉は軽微であった。液相部で認められた黒色スケール の成分は, 硫化鉄であることが確認された. なお, 気相 部の最大腐食速度は $0.4 \mathrm{~mm} / \mathrm{y}$ となった。

当該環境では, $\mathrm{H}_{2} \mathrm{~S}, \mathrm{NH}_{3}$ が高濃度で存在する環境であ り, 塩化物, シアンなどの他の腐食性物質は検出下限界 以下であること, また, 全面腐食 の形態を呈していることから，腐 食原因は $\mathrm{NH}_{4} \mathrm{HS}$ によるものであ ると推定した．更に，チューブ内 流速は腐食が発生した出口側で $2.1 \mathrm{~m} / \mathrm{s}$ と低く, Fig. 2 で示される 高せん断応力を受けたエロージョ ン・コロージョンが要因となる可 能性は低い, 従って, 当該部の腐 食は, 高濃度の $\mathrm{NH}_{4} \mathrm{HS}$ が局所的 に生成したことによる腐食と推定 した。

\section{3 実装置における腐食解析 3.3.1 液相 (プロセス水) での $\mathrm{NH}_{4} \mathrm{HS}$ 濃縮挙動}

当該空冷式熱交換器チューブの 腐食から, 気相部と液相部で明ら かに腐食程度が異なっていたた め, $\mathrm{NH}_{4} \mathrm{HS}$ 濃度に大きな違いが あると考えた。そこで, 液相, 気

Fig. 5 General flow of sour water stripper. 


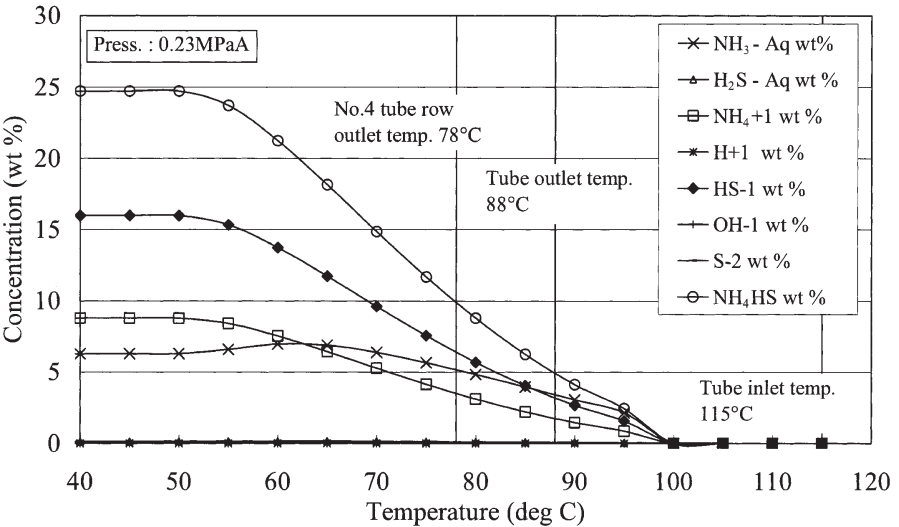

Fig. 8 Calculated chemical composition of the bulk water as a function of temperature according to the ionic model.

相における $\mathrm{NH}_{4} \mathrm{HS}$ の挙動を，シミュレーション結果と 実機の腐食状況を対比することにより解析した．液相で の $\mathrm{NH}_{4} \mathrm{HS}$ 濃度とはプロセス水に溶け込む $\mathrm{NH}_{4} \mathrm{HS}$ 濃度を 意味し，気相での $\mathrm{NH}_{4} \mathrm{HS}$ 濃度とは気相側で凝縮する水 中に溶け込む $\mathrm{NH}_{4} \mathrm{HS}$ 濃度を意味する。

液相における各種イオン及び $\mathrm{NH}_{4} \mathrm{HS}$ 濃度の温度との 関係を Fig. 8 に示す。この液相 の性状は，実装置においては， 空冷式熱交換器チューブで凝縮 した水，すなわちチューブの下 部を流れている水の性状を意味 する.この水は，下流のリフラ ックスドラムにおけるサンプル 採取により分析を行い，性状を 監視している.

解析には，電解質プロセスシ ミュレーション（OLI Stream Analyzer）を使用し，実装置の 条件を基に計算を実施した。そ の結果，温度の低下とともに $\mathrm{NH}_{4} \mathrm{HS}$ 濃度は上昇することが 確認された。但し，熱交換器出 口温度 $88^{\circ} \mathrm{C}$ での $\mathrm{NH}_{4} \mathrm{HS}$ 濃度は $10 \mathrm{wt} \%$ 以下であり，Daminの データからも SUS316 ステンレ ス鋼は腐食しない環境となる。 これは, チューブ下部の液相側
に腐食を認めていないことから，実装置におい てもこの事実を説明することができた。

\subsection{2 気相側の凝縮水中での $\mathrm{NH}_{4} \mathrm{HS}$ 濃縮挙} 動

次に，気相側の凝縮水中での $\mathrm{NH}_{4} \mathrm{HS}$ 濃度の 解析を実施した。通常, 汎用のシミュレーショ ンツールを用いると, 気液平衡計算を行うため 気相, 液相での性状が推定されるが, 気相部チ ューブ内表面に凝縮する微量の水における気液 平衡計算は実施していない。そこで，気相部チ ューブ内表面では，バルク流体での通常の気液 平衡とは別の気液平衡が局所的に形成されてい ると仮定し，気相側の凝縮水中での $\mathrm{NH}_{4} \mathrm{HS}$ 濃 縮モデルを構築した。

Fig. 9 に, 気相側の凝縮水中での $\mathrm{NH}_{4} \mathrm{HS}$ 濃縮 モデルの概念図を示す．気相部で凝縮する微量 の液滴状の水あるいは薄い水膜における平衡を, 平衡 II として，バルク流体での平衡 I と区別する。 そこで，こ の平衡 II における計算を行い，微量の凝縮水中に溶け込 む $\mathrm{NH}_{4} \mathrm{HS}$ 濃度の変化を算出した。

Fig. 10 に本解析に使用したモデルを示す。まず，廃水 ストリッパー塔頂ガスである流体 A において，熱交換器

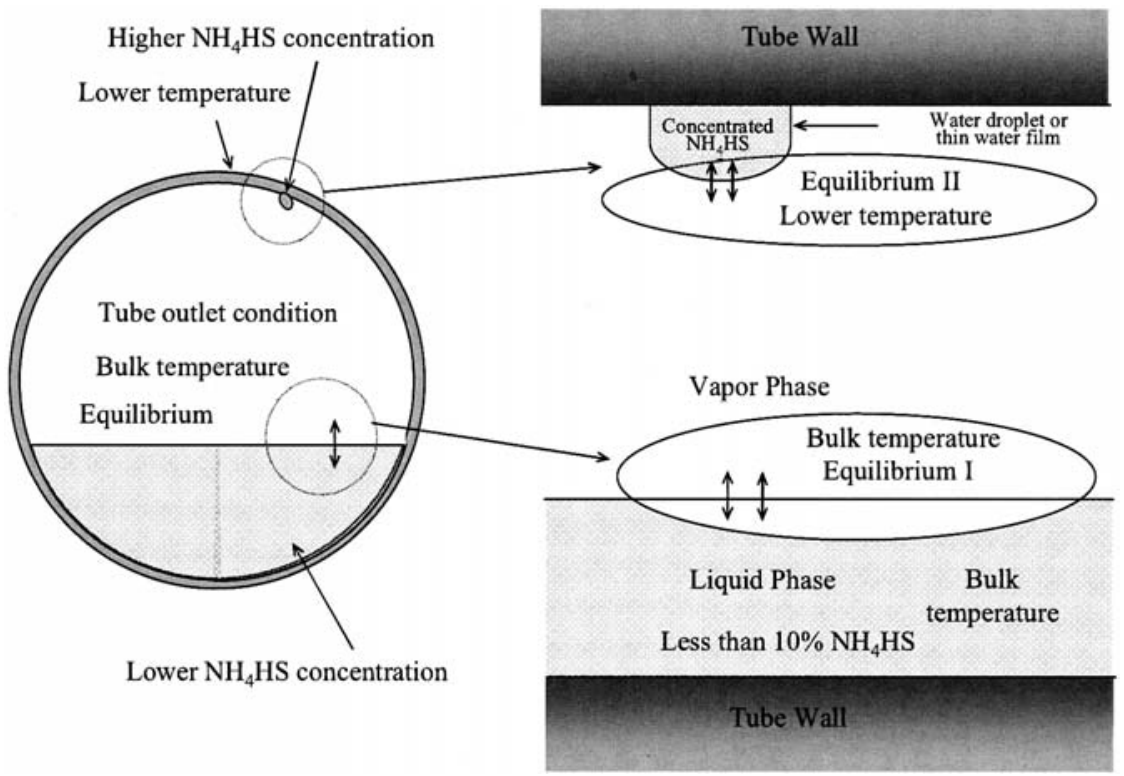

Fig. 9 Plausible mechanism for high $\mathrm{NH}_{4} \mathrm{HS}$ concentration in the condensed phase.

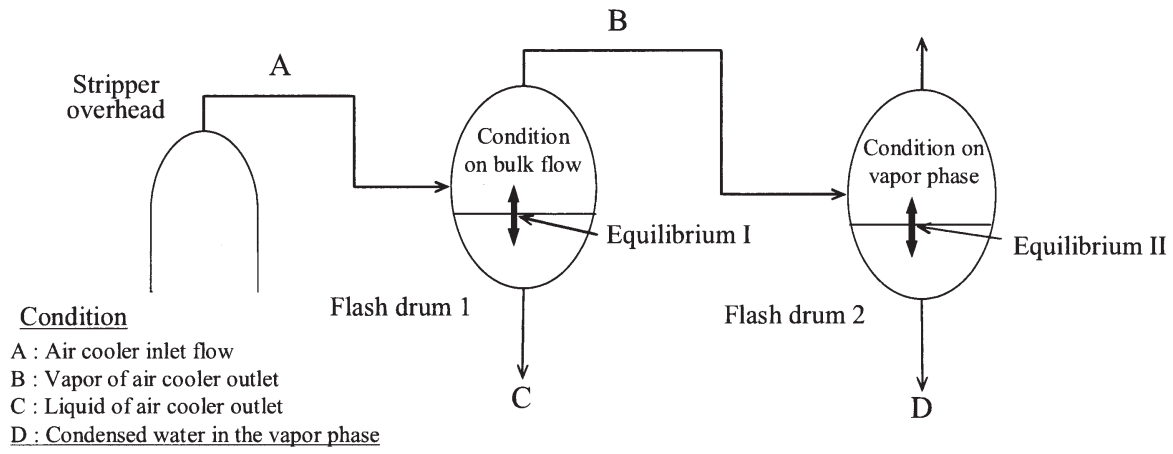

Fig. 10 Double equilibrium model for calculation of $\mathrm{NH}_{4} \mathrm{HS}$ concentration in the condensed water in the vapor phase. 
チューブの条件でフラッシュドラム 1 にて平衡計算させ る。これは従来の設計手法にて実施したバルク流体での 気液平衡計算である。流体 C はチューブ液相部の流体を 意味し, 通常この部分での $\mathrm{NH}_{4} \mathrm{HS}$ 濃度を推定し腐食評 価を実施する．Fig. 8 に示された $\mathrm{NH}_{4} \mathrm{HS}$ 濃度は, 流体 $\mathrm{C}$ における $\mathrm{NH}_{4} \mathrm{HS}$ 濃度の温度による変化を示したもので ある。次に，気相部の流体である流体 B を，更にフラッ シュドラム 2 にて平衡計算させる。ここで得られた液相 流体 D が気相側で凝縮する微量の液滴状の水あるいは薄 い水膜を示す．流体 Dにおける $\mathrm{NH}_{4} \mathrm{HS}$ 濃度の変化を算 出した。

Fig. 11 に気相側の凝縮水中の各種イオン及び $\mathrm{NH}_{4} \mathrm{HS}$ 濃度の温度による変化を示す。温度の低下に伴って $\mathrm{NH}_{4} \mathrm{HS}$ 濃度は増加するが，温度低下に従って $\mathrm{NH}_{4} \mathrm{HS}$ 濃 度は上昇し続けることが確認された。従って, 気相で局 所的に凝縮する微量の水の $\mathrm{NH}_{4} \mathrm{HS}$ 濃度は, 温度が低下 すると限りなく高濃度となることが本解析により確認さ れた。

\subsection{3 チューブ内流体及び管表面温度}

これまでの検討により，温度が低下すると，局所的に 気相側の凝縮水中において高濃度の $\mathrm{NH}_{4} \mathrm{HS}$ 環境となる ことが推定された。 そこで, 空冷式熱交換器チューブの どの部位で凝縮水中の $\mathrm{NH}_{4} \mathrm{HS}$ が高濃度となり，腐食が 発生する環境となるかについて検討した。当該空冷式熱 交換器ヘッダーは，1 パス，4段タイプであり，各チュ ーブのプロセス温度の分布を，熱交設計シミュレーショ ンによって算出した. Fig. 12 は, 各チューブの長手方向 におけるプロセス温度の分布を示したものである。 $115^{\circ} \mathrm{C}$ で空冷式熱交換器入口に入った流体は, 各チュー ブで冷却され，Fig. 12 のような温度勾配となる．空冷式 熱交換器出口温度は，これら 4 段のチューブ出口流体合 流後の温度として $88^{\circ} \mathrm{C} て ゙$ 管理されているが，最下段チ工 ーブの出口温度は $78^{\circ} \mathrm{C}$ となっており, 管理值よりも下回 っていることが確認された。 なお, 激しい腐食は最下段 チューブ出口部の Fig. 12 に示した箇所に認められた.

また，腐食を認めた最下段チューブにおいて，外気温 度を変化させた時の流体温度と管表面温度を算出した。 Fig. 13 に示すように, 外気温度の低下は，流体温度及び 管表面温度に大きく影響することが確認された。

最下段チューブでも，激しい腐食を認めたチューブと

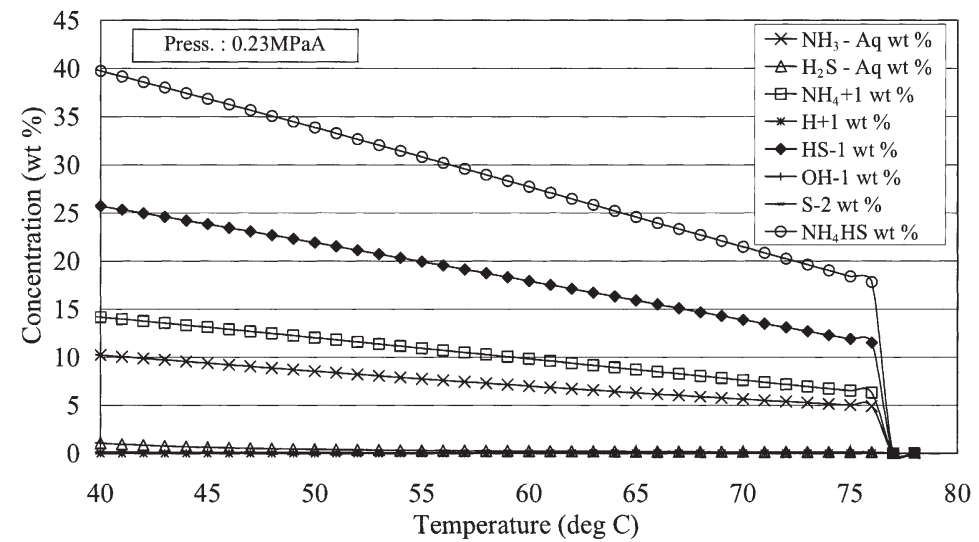

Fig. 11 Calculated chemical composition in the water droplet as a function of temperature according to the ionic model.

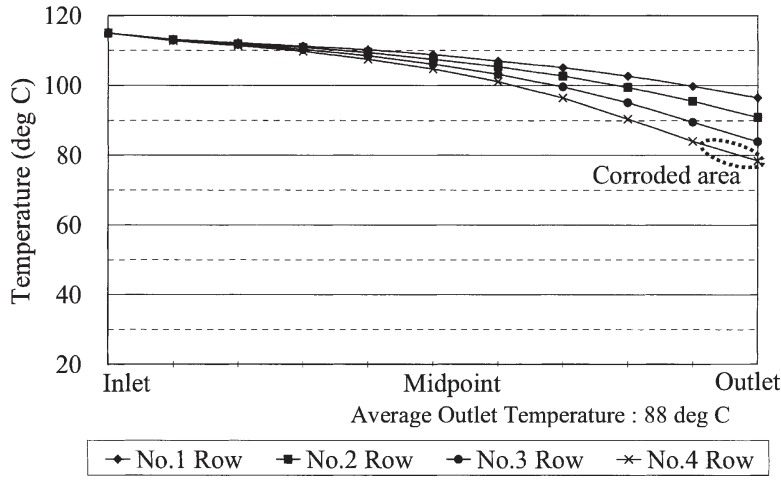

Fig. 12 Profile of process temperature in each tube row.

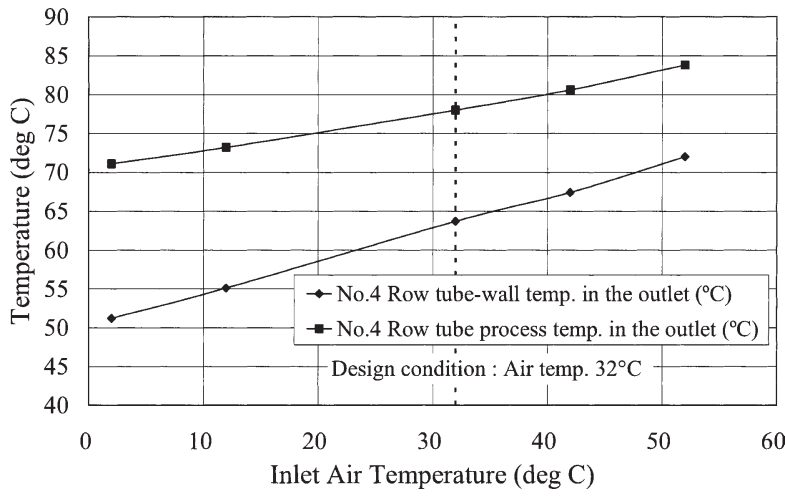

Fig. 13 Difference between process temperature and tube-wall temperature in the outlet of No. 4 tube row as a function of air temperature.

腐食が軽微であったチューブとが混在していた。設計上 は同じ段であれば同じ温度とみなされているが，実運転 では，ファンの稼動状態による風速の違いや流体分散不 均一によって, 場所により管表面温度は異なることが予 想される。 そこで, 空冷式熱交換器チューブ外表面に熱 伝対を設置し，温度測定を行った。減肉が激しかったチ ユーブと軽微であったチューブに設置し，温度差を確認 した。その結果，激しく腐食したチューブは，腐食が軽 微であったチューブよりも温度が低くなっていた，具体 的には，ファンの外側に位置するチューブは，内側に位

置するチューブよりも腐食が激しく，管表面 温度も低下していたことが分かった。これは， ファンの内側と外側で風速差が生じ，管表面 温度に影響を与えたものと考えられる。

\section{4. 考察}

\section{1 $\mathrm{NH}_{4} \mathrm{HS}$ 濃度と腐食速度の関係}

$\mathrm{NH}_{4} \mathrm{HS}$ は $35 \mathrm{wt} \%$ 以上の高濃度となると, 流速などのせん断応力の影響を受けなくても 激しく腐食することが，実験により確認でき た。腐食速度についてはDamin ら研究結果 と同等の值が得られた。 また，高濃度となる と錯イオン（アンミン鉄イオン）を形成し, 激しく腐食させることが示唆された。

特に, SUS316 ステンレス鋼においては, 


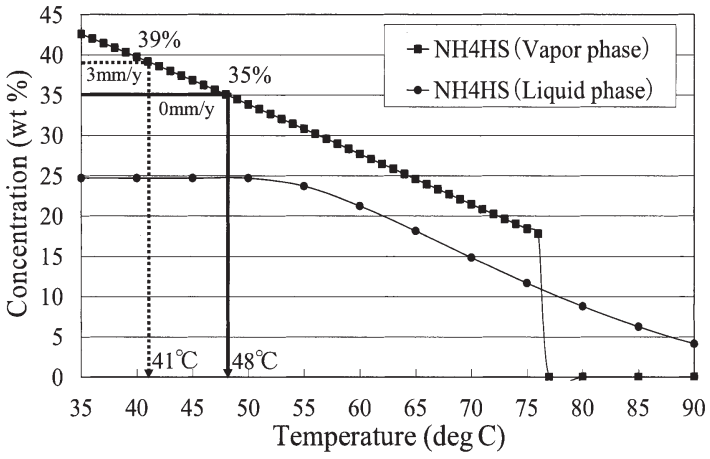

Fig. 14 Estimated corrosion rates in the condensed phase.

$35 \mathrm{wt} \%$ を越えると急激に腐食速度が増加するため，局所 的な濃縮も含めた $\mathrm{NH}_{4} \mathrm{HS}$ の濃度管理は厳密に行う必要 がある。

\section{2 気相側凝縮水中における腐食速度の推定}

腐食が発生したチューブにおける腐食速度の推定を行 った. Fig. 14 に気相側凝縮水中及び液相部における $\mathrm{NH}_{4} \mathrm{HS}$ 濃度の温度による変化を示す。 3.3 .1 及び 3.3.2 で述べたように気相側凝縮水では $\mathrm{NH}_{4} \mathrm{HS}$ 濃度は温度低 下とともに上昇し続けるが，プロセス水である液相では ある濃度で一定となり，実機において気相と液相では明 らかに腐食環境が異なることがシミュレーションでの解 析により確認された。更に, 気相部での腐食速度を評価 したところ，腐食試験により得られた $\mathrm{NH}_{4} \mathrm{HS}$ 濃度と腐 食速度の関係 (Fig. 6) から, Fig. 14 に示されるように, $\mathrm{NH}_{4} \mathrm{HS}$ 濃度が $35 \mathrm{wt} \%$ 以下では腐食速度は $0 \mathrm{~mm} / \mathrm{y}, 39$ $\mathrm{wt} \%$ で $3 \mathrm{~mm} / \mathrm{y}$ に達することが予測される。 その時の温 度は，腐食速度が $0 \mathrm{~mm} / \mathrm{y}$ の時は $48^{\circ} \mathrm{C}$ 以上，腐食速度が 0〜3 mm/y の時は $41 \sim 48^{\circ} \mathrm{C}$, 腐食速度が $3 \mathrm{~mm} / \mathrm{y}$ に達す る時の温度は $41^{\circ} \mathrm{C}$ となことが推定され, 温度の影響を 大きく受けることが示唆される。

\section{3 管表面温度に影響する因子}

今回実施した実機における管表面温度の測定の結果, 同じ段のチューブにおいても, 腐食が発生しているチュ ーブと腐食が発生していないチ ユーブで，大きな温度差があっ た。これは，ファンの位置によ り風速の分布が異なるため，管 表面温度に大きく影響するため と考えられる。実際には，ファ ンの外側に位置するチューブ は，中央部よりも温度が低下し ていたことが確認されている.

空冷式熱交換器の運転方法に よっても，風速に大きく影響を 与える.ルーバーの開度, ファ ンのピッチを変更することによ り, 風量は変化する. 温度コン トロールができる範囲でこれら を調整し，管表面温度を低下さ せないようにすることが望まし い.
今回のように，外気温が管表面温度により大きく影響 し，管表面温度のわずかな変化が腐食速度に大きく影響 する場合, 外気温の変化についても考慮する必要がある. ここで, 年間の実装置における外気温の変化を確認した. Fig. 15 に示すように，時期によって大きく温度差があり， 温度が低下した冬季に腐食は進行した可能性が高い。

空冷式熱交換器下部に内面に蒸気を通したヒーティン グコイルを設置する場合がある。これは，チューブ内部 流体の過冷却による製品の流動性低下や塩析出によるチ ユーブ内部での詰まりなどを防止するためである。この 機器の運用により, チューブに外表面にさらされる空気 温度が上昇し，管表面温度の低下を防止する。特に，寒 冷地で空冷式熱交換器を使用する場合は, 本事例のよう にチューブの過冷却による管表面温度の低下が，腐食環 境にも大きく影響するため, ヒーティングコイルの適用 は有効となる。

装置の稼働率が低下し, 対象部位の流量が低下するこ とにより，管表面温度の低下現象は発生しやすくなる. 管表面温度の変化と装置の稼働状況の変化の関係を把握 し，設計時に配慮することが必要と考えられる。

\section{5. 新防食設計手法}

本研究により得られた前述の結果から， $\mathrm{NH}_{4} \mathrm{HS}$ による 腐食環境での新たな防食設計の観点として, 以下の項目 を導入することが有効であることが分かった。

（1）気相凝縮水中での局所的な腐食性物質濃縮

通常, 機器や配管の腐食環境評価を行うために, 系と しての腐食性物質の濃度を推定する．当該部では系全体 の気液平衡計算により, 液相での濃度を推定し腐食環境 を評価する，ところが，実際には，気相での局所的な凝 縮水生成による腐食性物質の濃縮により, バルクの液相 とは腐食環境が大きく異なることから, 気相凝縮水中で の局所的な腐食性物質の濃縮を考慮することが有効であ る.

（2）空冷式熱交換器のファンの位置による管表面温度 への影響

通常, 空冷式熱交換器の設計では, 平均風速を使用し

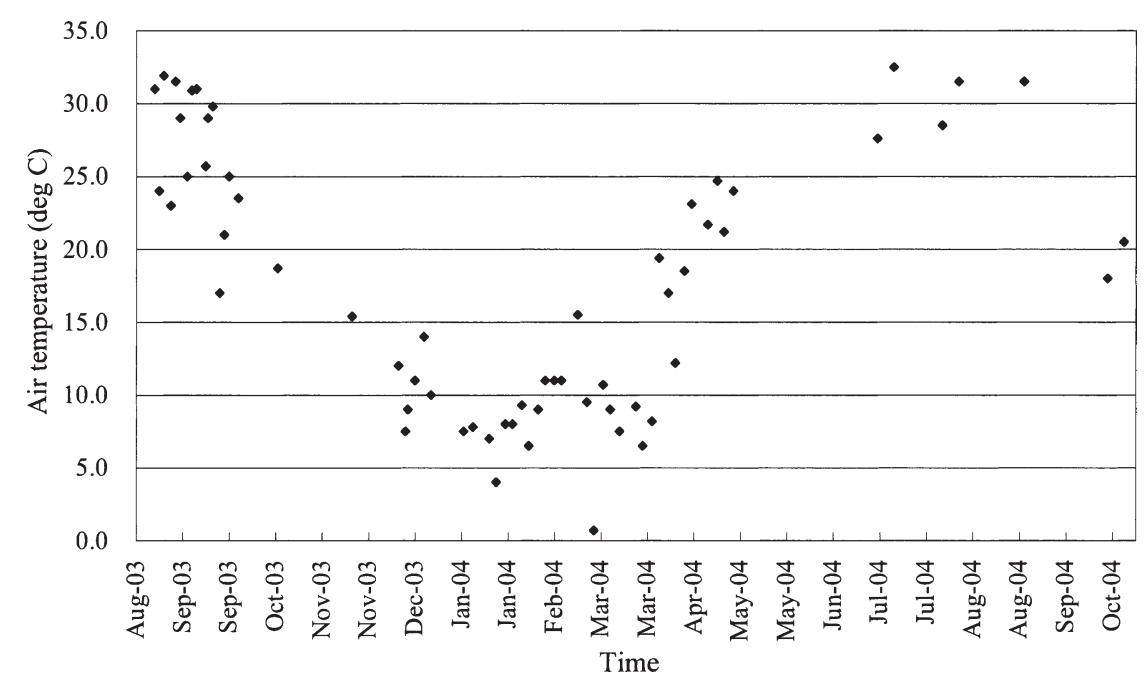

Fig. 15 Outside air temperature of the present unit. 
て冷却性能を評価する.しかし実際には, 同じ段のチュ ーブにおいても，ファンの外側における風速は高いと考 えられる。この部分ではチューブ冷却効果が大きいこと が，表面温度測定結果及び実際の腐食状況から確認され た。従って, 同じ段でも最も腐食環境が苛酷となる箇所 はファン外側であることを配慮することが有効である。

(3) 空冷式熱交換器のファンの運転方法による管表面 温度への影響

風速が高くなるにしたがって，管表面温度は低下する が, 風速は, 空冷式熱交換器の運転方法によっても調整 可能である. ファンのピッチ変更やルーバーの角度変更 によって，風速は大きく変化するため，防食対策として は有効な手段となる。

（4）外気温の変化による管表面温度への影響

通常, 空冷式熱交換器の設計には, 冷却性能において 最も筼しい条件としての, 夏季での外気温度が使用され る。しかし, 腐食環境が最も撖しくなるのは外気温度が 低下する冬季であることが分かった. よって, 設計時に は, 夏季での条件のみではなく, 冬季での外気温度も適 用することが重要となる。

（5）ヒーティングコイル適用

4.3 で述べたように，通常この設備は，チューブの過 冷却を防止する目的で設置されるが， $\mathrm{NH}_{4} \mathrm{HS}$ の腐食にも 大きく影響することが，本研究により明らかになった． よって，このヒーティングコイルは，防食対策のために も重要な設備となるため, 設計当初から設置し, 運用す ることが有効である。

(6) 装置の稼働状況

4.3 で述べたように, 低稼働時の腐食環境が最も苛酷 となるため, 設計時には, 対象装置の稼働率を把握した 上で，特に最低稼働時の管表面温度を算出し，防食対策 を施すことが必要となる。

\section{6. 結 論}

（1） 高濃度 $\mathrm{NH}_{4} \mathrm{HS}$ 水溶液による実験及び廃水ストリ ッパー塔頂空冷式熱交換器チューブの腐食解析の結果, 以下の事項が明らかとなった。

(a) $35 \mathrm{wt} \%$ 以上の高濃度 $\mathrm{NH}_{4} \mathrm{HS}$ 環境では, Damin ら の研究結果と同様に, 炭素鋼及び SUS316L ステン レス鋼で激しく腐食する。

（b）また，高濃度 $\mathrm{NH}_{4} \mathrm{HS}$ 環境では，高せん断応力を
うけなくても錯イオンを（アンミン鉄イオン）を形 成して，激しく腐食する。

（2）実機での腐食現象について，実運転デー夕を用 いた電解質プロセスシミュレーション及び熱交設計シミ ュレーションによる解析の結果, 以下の事項が明らかと なった。

(a) 空冷式熱交換器チューブの過冷却により, 気相部 では $35 \mathrm{wt} \%$ 以上の高濃度 $\mathrm{NH}_{4} \mathrm{HS}$ 環境となり激しく 腐食した。

(b) 空冷式熱交換器出口温度は, 各段チューブ出口合 流部での温度を管理しているが，最下段チューブの 流体温度は, 出口管理温度よりも低下しており, 管 内表面温度は更に低下する。

（c）管内表面温度には風速，空気温度，装置稼働率が 影響することが分かった，具体的には，空冷式熱交 換器に設置されているファンの位置, ルーバー開度, ファンのピッチ, また, 外気温度, ヒーティングコ イル採用の有無が，大きく影響する.

本解析結果を基に, 空冷式熱交換器チューブ気相部で の $\mathrm{NH}_{4} \mathrm{HS}$ による異常腐食を防止する新たな設計手法を 確立した。従来の空冷式熱交換器の設計は, 冷却性能を 満足する点に主眼を置き, 防食設計についてもバルク流 体での検討にとどまっていたが, 今後は, 流体気相部で の局所的な $\mathrm{NH}_{4} \mathrm{HS}$ 濃縮挙動も配慮するようにした。な お，偏流あるいはデポジットを伴った局所的な液相での 濃縮挙動については, まだ研究の余地がある。

\section{参 考 文 献}

1）石油産業活性化センター報告書「石油精製設備のオンラ イン腐食モニタリング技術に関する調査報告書」(平成 15 年 3 月), 財団法人石油産業活性化センター.

2) R. Horvath, M. Cayard and R. Kane, Corrosion 2006, Paper No. 06576, NACE International (2006).

3) D. Damin and J. McCoy, Materials Performance, p.23, NACE International (1978).

4) K. Toba, K. Kawano, K. Yamamoto and Y. Arakawa, Corrosion 2005, Paper No. 05569, NACE International (2005).

5) H. Iwawaki and K. Toba, Proc. JSCE Materials and Environments 2005, p.57, JSCE (2005).

6) H. Iwawaki and K. Toba, Corrosion 2007, Paper No. 07576, NACE International (2007).

7) H. Iwawaki, JPI Proceedings, p.37 (1997).

(Manuscript received June 9, 2009; in final form September 9, 2009)

\section{要旨}

$\mathrm{NH}_{4} \mathrm{HS}$ による腐食は，高濃度では異常な速さで進行する．特に，ある濃度を越えると急激に腐食が進 行する特徵があり，局所的な過冷却なども考慮した，防食面からの機器の解析・設計が望まれる. 特に当 環境を含む水素化脱硫装置，水素化分解装置等高圧設備では，腐食漏洩により大事故に至る可能性がある ため, 設計段階での防食面の配慮が必要である。そこで, 水素化脱硫装置付帯の廃水ストリッパーでの $\mathrm{NH}_{4} \mathrm{HS}$ による腐食事例を基に，シミュレーションを適用した腐食解析を実施し問題を解決するとともに， 防食設計の手法を確立したので，その内容を報告する.

キーワード＼cjkstart硫化水素アンモニウム, 石油精製, サワー環境, 設計 